\title{
On the development of genetic resources
}

\author{
G. SCHÖNMUTH, G. SEELAND
}

Sektion Tierproduktion und Veterinärmedizin der Humboldt-Universität zu Berlin, Bereich Tierzüchtung und Haustiergenetik, DDR 1040 Berlin, Invalidenstr. 42

Modern breeding programmes ensure good selection results to the breeder and reduce, at the same time, the genetic variation within and between the breeds of a given animal species. At present efforts are being made to counter that process and, through the establishment of gene pools, to maintain the genetic manifoldness of the useful animal species.

These measures alone are considered as insufficient. Efforts must be aimed at replacing the formerly in part unintentional work of practical breeding for the differentiation of breeds.

It ist suggested that today this task should be taken over by scientific institutes. Some promising breeding projects are outlined in the paper.

\section{Conservation of animals of local breed in extinction in the U.S.S.R.}

\author{
I.A. PARONIAN and K.M. IVANOV \\ All-Union Research Institute of Farm Animal Breeding and Genetics, \\ Leningrad, U.S.S.R.
}

Distribution areas and the size of the population to be remained were determined for every breed of 19 cattle breeds, 15 swine breeds, 16 sheep breeds and 14 horse breeds characterised by valuable and unique qualities. Special farms for genetic resources conservation were established. A gene pool bank for semen of sires belonging to 26 local and aboriginal cattle breeds was created. A system for breeding not numerous breeds was elaborated. It stipulates linear-group outbred selection with the rotation of 5-6 main sire lines and 5-6 genealogical groups of breeding stock.

\section{Utilization of gene pool of related breeds in improvement of Latvian Brown Cattle}

\section{D.A. STRAUTMANIS and I.A. BRUNOVSKIS}

Latvian Research Institute of Animal Husbandry and Veterinary, Sigulda, U.S.S.R.

In the Latvian S.S.R. the bulls of the Red Danish and Angler breeds are widely used in improvement of the Latvian Brown breed.

In 198032.4 p. 100 of all the dairy herd of the Republic were inseminated with the semen of the above bulls. No significant differences have been observed in the growth and development of crossbreds.

Purebred Anglers reached maturity earlier than the crossbreds.

The best results in productivity were showed by the crossbreds of $3 / 4$ Red Danish inheritance their milk yield records were by 20.3 p. 100 and milk fat records by 17 p. 100 higher than those of Latvian Brown cows.

The crossbreds of Angler origin demonstrated an increase in fat content by 0.05 p. 100 and milk fat by 13.7 p. 100 . 